\title{
Effects of inclusion of varying levels of dried Rice Distillers Grains with Solubles on the performance of Vanaraja birds
}

\author{
K. Pal ${ }^{\mathrm{a}}$, C. Maji ${ }^{\mathrm{b}}$ and B. Tudu ${ }^{\mathrm{c}}$
}

\begin{abstract}
${ }^{a}$ Subject Matter Specialist (Animal Science), North 24 Parganas Krishi Vigyan Kendra, West Bengal University of Animal and Fishery Sciences, Ashokenagar, Haripur, North 24 Parganas, West Bengal, India, 743223

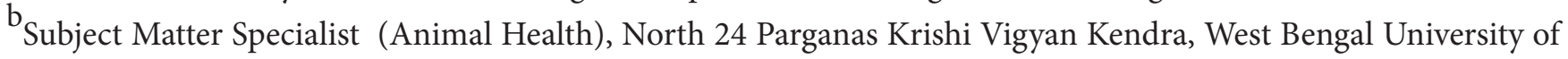
Animal and Fishery Sciences, Ashokenagar, Haripur, North 24 Parganas, West Bengal, India, 743223

${ }^{\mathrm{c}}$ Senior Scientist \& Head, North 24 Parganas Krishi Vigyan Kendra, West Bengal University of Animal and Fishery Sciences, Ashokenagar, Haripur, North 24 Parganas, West Bengal, India, 743223
\end{abstract}

Corresponding author: Kaushik Pal | Email: kpalvet@gmail.com

Co-author: CM: chinmoy_19@rediffmail.com, BT: dr13tudu@gmail.com

Received: 17-10-2020, Accepted: 14-12-2020, Published online: 20-12-2020

\begin{abstract}
Incorporation of unconventional feed ingredients in poultry ration plays a pivotal role in successful and economic poultry production. Distillers Dried Grains with Soluble is now becoming a popular unconventional ingredient for livestock as well as poultry feed due to its high nutritive value and lower price. In West Bengal Rice based Distillers Dried Grains with Soluble (RDGS) is predominantly available. When it comes to feeding Dried Rice Distillers Grains with Solubles (RDGS) to poultry birds, there is no formal recommendation regarding dietary concentration. Hence, the present study was conducted to assess the effects of varying levels of RDGS inclusion on "Vanaraja" chicken production performance. Total 144 numbers of Vanaraja birds were included to conduct the present study. They were divided randomly into three (3) groups $(n=48)$ with three (3) different dietary treatments that includes Control (C) without inclusion of RDGS, Treatment - I (T1) with 6\% RDGS inclusion of the total diet / day and Treatment - II (T2) with 12\% RDGS inclusion of the total diet / day respectively. The experiment continued up to 32 weeks of age of the birds. The performance parameters on the basis of body weight (BW) and egg production upto that age were recorded. Result showed that inclusion of RDGS increased body weight of the birds significantly than the group without inclusion of RDGS. Among the two supplemented groups the treatment group II (T2) i.e. inclusion of RDGS @ 12\% of the total diet /day was having maximum body weight $(2678.37 \pm 5.20 \mathrm{~g} /$ bird at 32 weeks). The egg production per hen also significantly increased in the supplemented groups than the non supplemented group. So among the two doses of RDGS inclusion, the second group (T2) showed best result. Therefore, it can be concluded from the above study that in rural condition where low quality feed is available to the birds, inclusion of RDGS as a protein source is beneficial to the birds.
\end{abstract}

Keywords: Dried Rice Distillers Grains with Solubles (RDGS), Vanaraja Birds, Production performance

doi: https://doi.org/10.51128/jfas.2020.A021 / How to cite this article: Pal, K., Maji, C. and Tudu, B., 2020. Effects of inclusion of varying levels of dried Rice Distillers Grains with Solubles on the performance of Vanaraja birds. Journal of Food and Animal Sciences, 01 (02): 117 - 120.

Copyright: Pal et al., 2020. Open Access. This article is distributed under the terms of the Creative Commons Attribution 4.0 International License (http://creativecommons.org/licenses/by/4.0/), which permits unrestricted use, distribution, and reproduction in any medium, provided you give appropriate credit to the original author(s) and the source, provide a link to the Creative Commons license, and indicate if changes were made. The Creative Commons Public Domain Dedication waiver (http://creativecommons.org/publicdomain/zero/1.0/) applies to the data made available in this article, unless otherwise stated. 


\section{Introduction}

Poultry is one of the fastest growing segments of the agriculture sector in India. A major constrain affecting the growth of the poultry industry in India is price and availability of feed resources. Poultry industry is highly dependent on the feed because feed alone constitutes $65-70$ per cent of the total cost of production. Therefore, any price fluctuation in the feed will have a direct impact on the prices of eggs and meat. Shortage of conventional feed ingredients drives the researchers on investigation of alternative feed resources. Utilization of unconventional feed ingredients in poultry ration is a key determinant of successful poultry production. Distillers Dried Grains with Soluble (DDGS) is now becoming a popular unconventional and low-cost ingredient for livestock feed due to its high nutritive value (Addison et al., 2018). DDGS is a co-product from the ethanol industry that is obtained by fermentation of cereal grains. DDGS has been recognized as a good source of protein, energy, water soluble vitamins and minerals, amino acids for poultry (Wang et al., 2007) and a valuable source of xanthophylls and linoleic acid as well (Runnels, 1957).

Earlier work showed that feeding of DDGS (at $5 \%$ level) in broiler starter diet and up to $12 \%$ to $15 \%$ in grower diet had no negative impact on production parameters. DDGS can be included up to $15 \%$ in layer diet and results showed increased yolk pigmentation
(Lumpkins et al., 2004). There is no formal recommendation, regarding dietary concentration, when it comes to feeding distillers dried grains with solubles (DDGS) to young broilers and other poultry birds. Moreover, there are not many reports on the effect of supplementation of DDGS on improved varieties or desi-chicken. Vanaraja is a popular dual purpose variety of improved LIT chicken developed by ICAR-DPR, Hyderabad. Dried Rice Distillers Grains with Solubles (RDGS) has been used for this study as rice is predominant in West Bengal. So the present study was undertaken to assess the level of inclusion of RDGS in the diet of Vanaraja chicken for optimum production and to study the effects of inclusion of RDGS in varying levels on the performance of Vanaraja chicken.

\section{Methodology}

The present study was conducted in the poultry demonstration unit of North 24 Parganas KVK, Ashokenagar, North 24 Parganas, West Bengal. Total 144 numbers of Vanaraja birds were taken for this study. The birds were randomly distributed into three (3) different groups (C, T1 and T2) consisting of 48 birds in each group with different dietary treatments viz. C - without RDGS, T1 - @ 6\% RDGS of total diet / day and T2 - @ 12\% RDGS of total diet / day. Each group had three (3) replicates consisting of 16 birds in each replicate. Rice Distillers Grains with Solubles

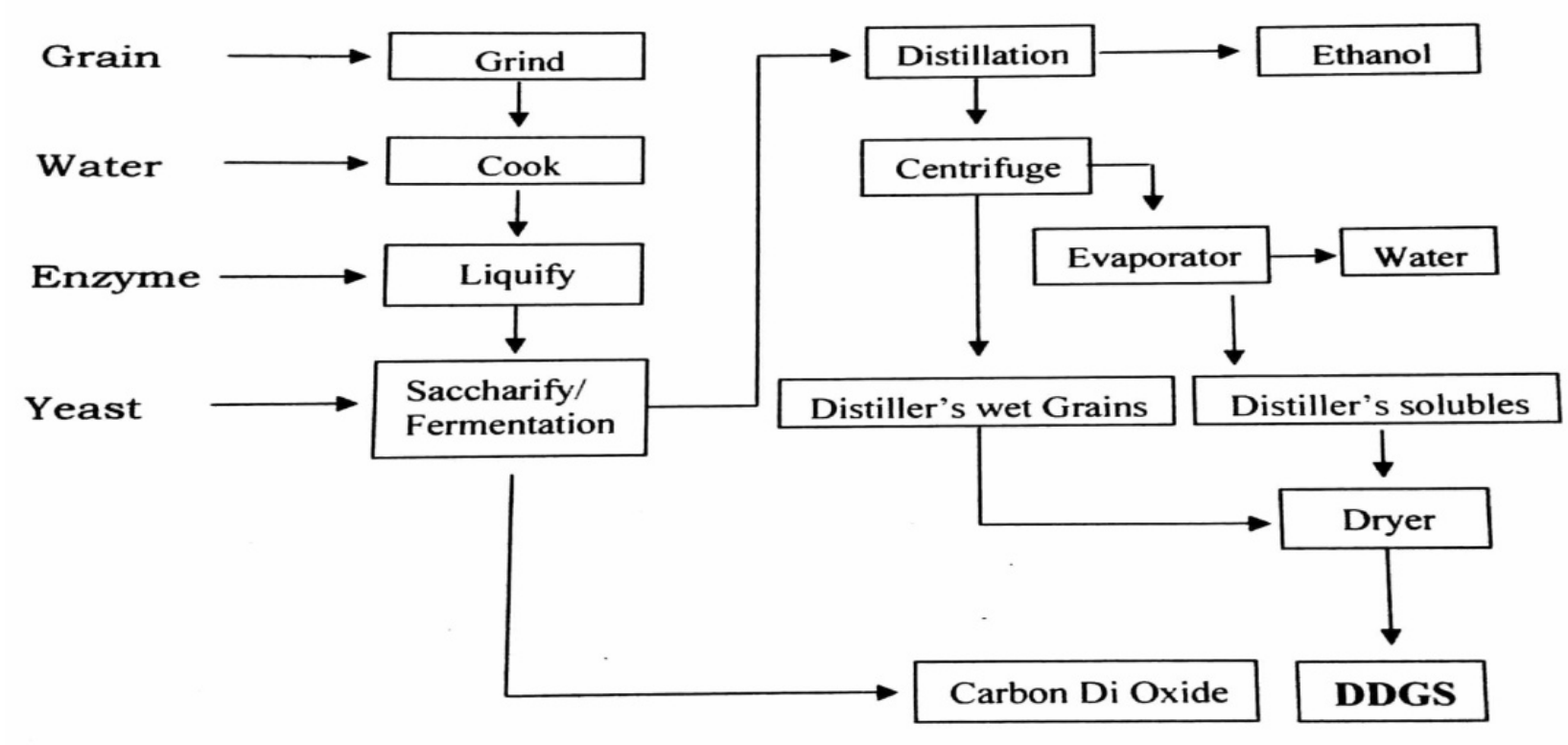

Figure 1: Process of preparation of DDGS 
(RDGS) were dried and used for incorporation in the diet. Total diet was divided into three parts and feeding was done three times a day.

Table - 1: Composition of RDGS (on DM basis)

\begin{tabular}{|c|c|}
\hline Parameter & Quantity (\%) \\
\hline Moisture & 10 \\
\hline Protein & $32-34$ \\
\hline Oil \& Fat & $9-10$ \\
\hline Fiber & $8-10$ \\
\hline Sand \& Silica & 2.5 \\
\hline
\end{tabular}

Ad libitum clean drinking water was provided throughout the day. Vaccination was done as per standard schedule. The feeding trial continued up to 32 weeks ( 8 months) and data recorded up to that period. Body weight was measured early in the morning before feeding at two weeks interval. Egg production data was recorded on daily basis after the birds started laying. The parameters studied during the experiment are average body weight (BW), average body weight gain (BWG), age at first lay, total egg production per hen and average egg weight.

Mean, standard error of mean and range of various parameters were estimated and test of significance (One way analysis of variance and Duncan test) between different groups were performed using SPSS (1997) for Windows (version 16.0; Microsoft).

\section{Results and discussion}

The effects of feeding of RDGS on monthly body weight $(\mathrm{g})$ of the Vanaraja birds from 0 day to 32 weeks of age are presented in the Figure -2 . Significant changes in the body weight were observed in the treatment groups than the control. Among the two treatment groups body weight were significantly higher in the T2 group (2020.18 $\mathrm{g}$ at $16^{\text {th }} \mathrm{wk}$ and $2678.37 \mathrm{~g}$ at $32^{\text {nd }} \mathrm{wk}$ ) than the T1 group (1908.12 $\mathrm{g}$ at

Figure 2: Body Weight changes of the Vanaraja birds fed RDGS at different ages

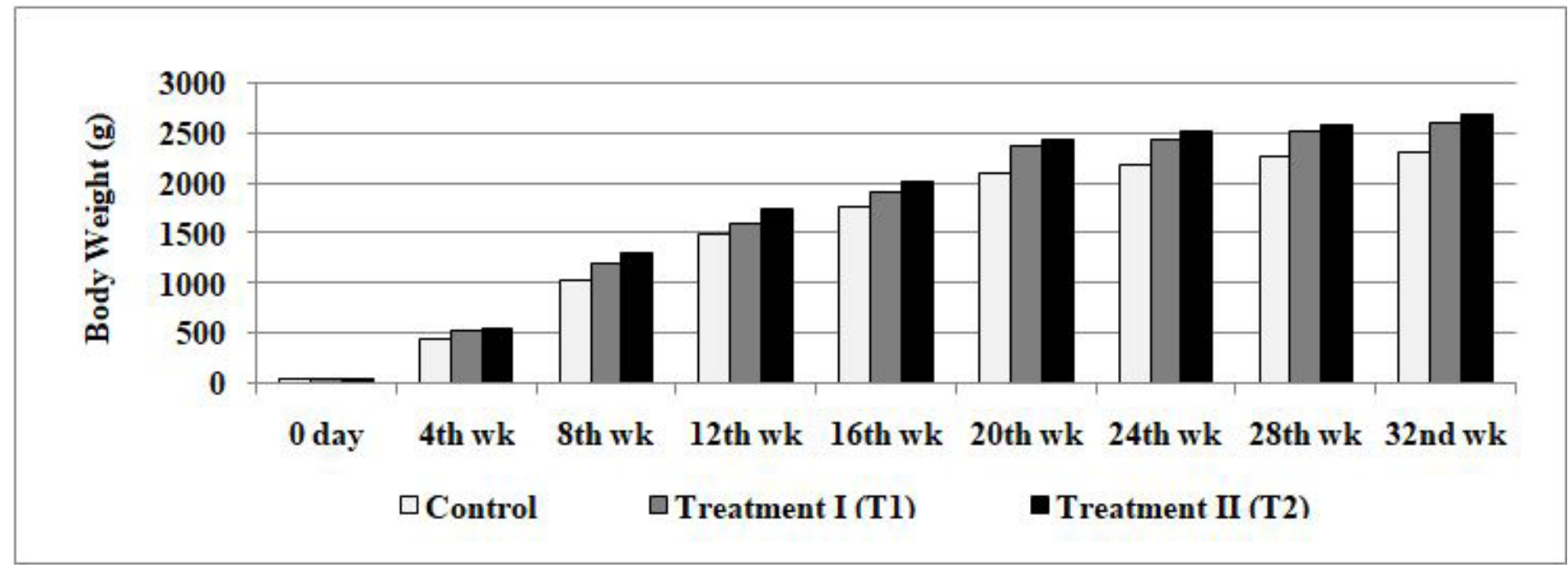

Table 2: Effect of feeding RDGS on egg production of Vanaraja birds up to 32 weeks of age

\begin{tabular}{|l|c|c|c|}
\hline \multicolumn{1}{|c|}{ Groups } & Age at first lay (days) & Total No. of eggs/hen & Average egg wt. (g) \\
\hline Control (C) & $169.17 \pm 0.72^{\mathrm{a}}$ & $51.50 \pm 0.39^{\mathrm{a}}$ & $53.70 \pm 0.29^{\mathrm{a}}$ \\
\hline Treatment I (T1) & $151.17 \pm 0.55^{\mathrm{b}}$ & $60.67 \pm 0.51^{\mathrm{b}}$ & $59.57 \pm 0.44^{\mathrm{b}}$ \\
\hline Treatment II (T2) & $142.83 \pm 0.68^{\mathrm{c}}$ & $62.83 \pm 0.44^{\mathrm{c}}$ & $60.83 \pm 0.52^{\mathrm{b}}$ \\
\hline SEM & 0.719 & 0.491 & 0.471 \\
\hline P value & 0.000 & 0.000 & 0.000 \\
\hline
\end{tabular}

Values followed by different letters $(\mathrm{a}, \mathrm{b}, \mathrm{c})$ within the same column differ significantly $(\mathrm{P}<0.05)$ 
$16^{\text {th }}$ wk and 2593.82 at $\left.32^{\text {nd }} w k\right)$. Similar results were reported by Kaya and Sahin (2013) where they fed DDGS up to $15 \%$ to the broilers.

The egg production performance data are presented in the Table -2 . The age at first lay was significantly lesser in RDGS supplemented groups than the control. Total number of eggs per hen were highest in T2 (62.83) then in T1 (60.67) and in control it was 51.50. Average egg weight was significantly higher in supplemented groups $(60.83 \mathrm{~g}$ in T2 and $59.57 \mathrm{~g}$ in $\mathrm{T} 1)$ than the control $(53.70 \mathrm{~g})$. However, there were no significant differences between the two treatment groups in respect to average egg weight. Similar effects were found by Sedmake et al. (2018) where they mentioned these positive results may be due to the amino acid composition and the potential bioavailability of these amino acids. The fiber content of the RDGS also may play pivotal role for better performances.

\section{Conclusion}

Findings of the present study suggest that inclusion of Rice Distillers Grains with Solubles (RDGS) bettered the performances of Vanaraja birds and can be included up to $12 \%$ of total diet of the birds as a source of protein especially in rural condition where low quality feeds are available to the birds by scavenging method.

\section{Authorship contribution statement}

K.Pal:Conceptualization, Methodology,Investigation, Collection of data \& data analysis, Writing - original draft, Writing - review \& editing, Supervision.

C. Maji : Conceptualization, Methodology, Writing review \& editing, Supervision.

B. Tudu: Conceptualization, Writing - review \& editing.

\section{Acknowledgments}

The authors are grateful to the ATMA, North 24 Parganas for providing the fund to conduct the study, the West Bengal University of Animal and Fishery Sciences, Belgachia, Kolkata, for extending help to conduct the research and to the IFB Agro Industries Limited, Noorpur, South 24 Parganas, West
Bengal for extending help in procuring the RDGS to conduct the research.

\section{Funding}

This research work was funded by the PD, ATMA, North 24 Parganas district, West Bengal.

\section{Declaration of Competing Interest}

All authors declare that there exist no commercial or financial relationships that could, in any way, lead to a potential conflict of interest.

\section{References}

Addison, M., Sarathchandra, G., Gnanaraj, P., Valavan, S. and Preetha, S. 2018. Effect of Supplementation of Distiller's Dried Grain with Soluble (DDGS) on Desi-Chicken Performance and Carcass Characteristics. Int. J. Livest. Res., 8(10): 327-337.

Kaya, O. and Şahin, T. 2013. Effects of different levels distillers dried grains with solubles on growth performance, carcass quality and some blood parameters in broilers. Kafkas Univ. Vet. Fak. Derg., 19(1): 161-166.

Lumpkins, B.S., Batal, A.B. and Dale, N.M. 2004. Evaluation of distillers dried grains with solubles as a feed ingredient for broilers. Poult. Sci., 83(11): 1891-1896.

Runnels, T. D. 1957. Corn distillers dried solubles as a growth promoting and pigmenting ingredient in broiler finishing diets. In Proc. Distillers Feed Research Council Conference, Cincinnati, Ohio, 12: 54-60.

Sedmake, E., Khose, K., Manwar, S., Gole, M., Wade, M. and Wankhede, S. 2018. Effect of Feeding Corn Distiller's Dried Grains with Solubles on Egg Quality Traits in Commercial Layers. Int. J. Livest. Res., 8(8): 273-284.

SPSS. 1997. Statistical Package for Social Sciences, Base Applications Guide 7.5. SPSS, Chicago, USA.

Wang, Z., Cerrate, S., Coto, C., Yan, F. and Waldroup, P. W. 2007. Utilization of distillers dried grains with solubles (DDGS) in broiler diets using a standardized nutrient matrix. Int. J. Poult. Sci., 6: $470-477$. 